\title{
Malnutrition in Long-Term Hospitalized Patients
}

\section{Uzun Süre Hastanede Yatan Hastalarda Malnütrisyon}

\author{
Gülsün Özdemir Aydın, Nuray Turan, Hatice Kaya \\ İstanbul University, Florence Nightingale Faculty of Nursing, İstanbul
}

\begin{abstract}
Malnutrition is a very serious problem in long term hospitalized patients. Malnutrition is associated with negative outcomes for patients, including higher infection and complication rates, increased muscle loss,impaired wound healing, longer hospital stays, and increased morbidity and mortality. Despite the seriousness of malnutrition, there is not enough emphasis on its diagnosis, prevention and treatment. In this context, increasing the awareness of malnutrition would have positive clinical results.
\end{abstract}

Key words: malnutrition; nutrition; nursing care

\section{ÖZET}

Uzun süre hastanede yatan bireylerde malnütrisyon önemli bir sorundur. Enfeksiyon, kas kaybı, yara iyileșmesinde gecikme, hastane kalıș süresinde uzama, morbidite ve mortalite oranlarında artıșa neden olmaktadır. Malnütrisyon bu kadar ciddi bir sorun olmakla birlikte uygulamaya bakıldığında tanılanması, önlenmesi ve tedavisine yeterince önem verilmediği görülmektedir. Bu bağlamda sağlık ekibi içerisinde malnütrisyona ilișkin farkındalığın arttırılması klinik önem göstermektedir.

Anahtar kelimeler: malnütrisyon; beslenme; hemșirelik bakımı

\section{Introduction}

Malnutrition is a comprehensive term that is used to define an individual's status of being inadequately nourished. Malnutrition may occur during illness when the need for nourishment increases but the intake of nutrients is inadequate or when there is a failure to absorb nutrients or in the case of an extreme loss of nutrients due to underlying diseases. When these factors are combined, malnutrition presents as a serious complication that affects multiple organs and systems in the body. Infection, muscle loss, delays in wound healing and extensions of hospital stays may increase morbidity and mortality rates ${ }^{1,2}$.

Asistan Gülsün Özdemir Aydn, Abide-i Hürriyet Cad. Sisli, Istanbul - Türkiye, Tel.02124402000Email.gulsunoz@istanbul.edu.tr

Geliş Tarihi: 15.01.2015 • Kabul Tarihi: 15.12.2015
The European Society of Parenteral and Enteral Nutrition (ESPEN) makes important distinctions in the definition of malnutrition, to differentiate the terms "cachexia,', sarcopenia" and "malnutrition". Cachexia which is a multi-factor syndrome chacracterized by severe loss of body weight, fat and muscle is mostly displayed as increased protein catabolism. The malnutrition is in hospitalized patients may be accompanied by cachexia (illness-associated) but also be unaccompanied $^{3}$.

The risk of developing malnutrition increases as the stay in the hospital is extended. For this reason, patients hospitalized for long periods of time pose a serious issue that must be addressed. Although malnutrition is a serious problem, a closer look at practices reveals that not enough importance is placed on diagnosing, preventing and treating this condition. In this context, it is of clinical significance that awareness about malnutrition should be raised among healthcare professionals.

The literature shows that the high risk of malnutrition as a result of receiving inadequate nourishment is known and attention is called to the many factors involved. These factors can be considered in two groups: factors stemming from the patient and those stemming from the healthcare team. Patient-related factors include age, apathy and depression, illness (cancer, diabetes, cardiac, gastrointestinal conditions), drug treatment, problems with chewing and swallowing, motor restrictions, impaired smell and taste, and treatment methods (ventilation, surgery, drains). Factors related to the healthcare team are described as the failure of health professionals to recognize malnutrition, deficiencies in the systems of screening and evaluation, uncertainties in nutrition education and responsibilities related to nutrition, missing height and weight records, gaps in medical records related to the patient's oral intake, and a general inability to grasp the importance of nutrition ${ }^{2,4,5}$. 


\section{Malnutrition Screening and Evaluation}

Diagnosing malnutrition or assessing the risk of malnutrition forms the foundation of treatment. The use of tools can aid the health team in identifying nutritional risks, evaluating nutrition, correctly identifying patients at risk of malnutrition and in increasing the effectiveness of the treatment a patient is receiving. Nutritional support is generally provided to patients by their doctors, nurses and dieticians but the time allotted for this purpose is inadequate ${ }^{2}$. Because of this, many hospitals are unable to identify the development of malnutrition and consequently, the process of evaluation and treatment of malnutrition is ultimately neglected.

Identifying nutritional status not only reveals the existence, risk and degree of malnutrition, but it also sheds light on the effectiveness of nourishment. The diagnosis is based on the patient's medical history, physical examination (muscle mass, muscle loss, fat storage, edema, acids), anthropometric measurements (body weight, height, body mass index, triceps' size), laboratory tests (creatinine, serum transferrin, serum albumin, prealbumin), and functional tests (hand dynamometer, direct muscle stimulation, respiratory and immune function tests). Furthermore, doctors and nurses may also use identifying tools for which validity and reliability tests have been carried out to identify a patient's nutritional status. As known, the various screening and evaluation instruments available, with respect to nutrition, facilitate the identification of risk and the process of diagnosis (Table 1$)^{6-8}$.

Table 1. Methods of assessing the nutritional status with various parameters

Nutritional Status Evaluation Tools

Prognostic Nutritional Risk Index (PNI)

Nutritional Risk Index (NRI)

Geriatric Nutritional Risk Index (GNRI)

Maastrict Index (MI)

Instant Nutritional Assessment (INA)

Determining a Nutritional Health Check List (DETERMINE)

Simplified Nutrition and Appetite Questionnaire (US - SNAQ)

Short Nutritional Assessment Questionnaire (Dutch - SNAQ)

Nutritional Risk Screening 2002 (NRS - 2002)

Subjective Global Assessment (SGA)

Malnutrition Universal Screening Test (MUST)

Protein Energy Malnutrition Scale (PEMS)

Malnutrition Risk Scale (SCALES)

Mini Nutritional Assessment (MNA)

Mini Nutritional Assessment-Short Form (MNA - SF)

\section{Hospital and IIIness-Related Prevalence of Malnutrition}

The main cause of malnutrition in developed countries is generally illness. Many studies conducted over the last 30 years have emphasized the seriousness of illnessrelated malnutrition in hospitalized patients. Whether it is acute or chronic, malnutrition is triggered by more than one factor. Malnutrition is commonly observed in patients with chronic liver disease, chronic cardiac disease, kidney failure, acquired immune deficiency syndrome (AIDS), chronic obstructive pulmonary disease (COPD), inflammatory intestinal conditions, neurodegenerative diseases and other chronic conditions, as well as in patients hospitalized for malignant diseases ${ }^{9}$. The assessment of malnutrition prevalence in studies varies between $20 \%-60 \%{ }^{10,11}$. In a screening of 9336 persons at a hospital in the UK, it was found that $28 \%$ of the patients were at risk of malnutrition, $43 \%$ of those who had developed malnutrition were suffering from digestive system ailments, $33 \%$ had neurological conditions, $21 \%$ cardiovascular disease and $18 \%$ had musculoskeletal disorders ${ }^{11}$. In Turkey, Korfalı et al. (2009) reported in a study they conducted in 62 hospitals that $15 \%$ of the 29,139 persons they assessed had developed malnutrition. It was found that $52 \%$ of intensive care unit patients, $43.4 \%$ of medical oncology patients, $23.9 \%$ of neurology patients, $24 \%$ of hematology patients, $19.1 \%$ of gastroenterology patients, $18.3 \%$ of gastrointestinal surgery patients, $18.2 \%$ of thoracic surgery patients, $16.4 \%$ of internal medicine patients, $10.3 \%$ of cardiology patients, and $10.9 \%$ of cardiac surgery patients had developed malnutrition ${ }^{12}$. In a study conducted by Sungurtekin et al. (2004) using two different nutritional screening tools, it was observed that $36 \%$ of patients at a hospital were suffering from malnutrition ${ }^{13}$. In Bayır's study (2012) on malnutrition rates in cases undergoing open-heart surgery and determining related risk factors, it was revealed that $20 \%$ of patients suffered from malnutrition and that hospital stay durations for these patients was longer than for other patients. The study also reported that patients with longer hospital stays were more likely to develop malnutrition than patients who were present for shorter stays ${ }^{14}$.

\section{Treatment and Care in Malnutrition}

Patients who are screened, evaluated and found to be at risk of malnutrition are started on nutritional support. This treatment involves oral intake of nutrients, the type of which varies according to the preferences of 
the individual, and in patients with no capacity for oral intake, the patient is fed parenterally ${ }^{15}$. Enteral nutrition (EN) is indicated in patients with adequate digestive and absorptive capacity of the gastrointestinal tract but who cannot eat enough. Enteral nutrition offers many advantages when compared to parenteral nutrition. These are the normalization of enteral nutrition intestinal functions in a shorter time, having lower risk of infection, being more suitable for human physiology, its easier application, being cheaper than parenteral nutrition, less occurrence of metabolic and septic complications, lower mortality and morbidity rates, applicable with fewer personnel and being ready to use $\mathrm{e}^{16-18}$. However, nutrition tolerance of the patient (e.g. nausea, vomiting), nursing practices (e.g. the change of body position and nutrition arrest), other medical procedures and nutrition programs that are not prepared according to the individual are among the major factors adversely affecting enteral nutrition ${ }^{19}$.

Parenteral nutrition (PN) is another form of nutrition that enables nutrition for patients with gastrointestinal limited absorption capacity who cannot be nourished functionally or enterally. Although it positively affects the patient's course of recovery when properly applied to the correct patient, its use causes the increase of infectious complications, the formation of metabolic complications and cost increase when preferred wrongfully. Therefore, it is essential to apply PN in case of failure to meet the nutritional requirements enterally and in patients who are unable to take oral implementing at least 7 days. Parenteral nutrition is applied in two ways as peripheral parenteral nutrition and central parenteral nutrition. The decision to implement PN requires a multidisciplinary approach ${ }^{20}$.

The beneficial effect of parenteral nutrition (PN) in improving the nutritional status of hospitalized patients who are malnourished is well established ${ }^{21}$. However, several retrospective and prospective studies have shown that the use of $\mathrm{PN}$ is an independent risk factor developing the other health problems ${ }^{22}$. PN is a costly technology and can also be associated with complications such as electrolyte disturbances, hyperglycaemia, hypertriglyceridaemia, as well as hepatobiliary, infectious and mechanical complications ${ }^{23}$. Considering these complications caused by it, individual nutritional solution should be selected considering the condition of the patient while deciding on PN support.

After deciding upon the route to be taken in feeding the patient, the daily calorie need is then calculated.
Depending upon the clinical condition of the patient, the choice between enteral and parenteral nutrition is an important factor in achieving tolerance and preventing complications. Products that need to be used in tube feeding should not be administered orally and the patient should be monitored in terms of complications such as nausea, vomiting, diarrhea, pulmonary aspiration, fluid overload, electrolyte imbalance, dehydration, hyperglycemia or the development of an infection. Bodoky\& Smith (2009) state that diarrhea is a complication that can be prevented with enteral nutrition and that nausea and vomiting must be prevented because of the risk of aspiration ${ }^{24}$. The speed, amount and level of tolerance to products administered via the enteral route (gastric residue, distension) must be strictly controlled. Studies have shown that nurses are not adequately equipped to identify the nutritional needs of tube-fed patients, that they do not adequately consult the guides and display a general lack of knowledge, being therefore unable to provide suitable care ${ }^{25,26}$. In another study conducted by Uysal et al. (2011), it was reported that nurses were precise about following up on the administration of the feeding, the nutrients, the speed the products were administered, their amounts and the gastric residue status at 4-6 hour intervals ${ }^{27}$.

Patients who receive nutritional support need to be monitored in terms of their vital signs and weight as well as through a weekly evaluation of anthropometric measurements and laboratory tests (albumin, etc.). In a follow-up study on the nutritional status and development of malnutrition in in-patients at a hospital, Güngör (2009) found that $77 \%$ of hospitalized patients displayed an average weight loss of 3.9 $\mathrm{kg}$ despite their nutritional support. These patients' body mass index values fell as the duration of the hospital stay increased ${ }^{5}$. In situations where enteral feeding is not possible, the nutritional needs are met with parenteral feeding. Products to be administered via the parenteral route may be applied peripherally or centrally. In PN status, it is important to watch the patient for infection symptoms and findings and monitor for air embolisms, hyperglycemia, hypoglycemia and circulatory overload ${ }^{27-29}$. A study by Küçük et al. reports that $17 \%$ of patients developed infections and $52.1 \%$ experienced hyperglycemia ${ }^{30}$.

\section{Conclusion and Recommendations}

To prevent malnutrition, it is important to evaluate the nutritional status of hospitalized patients and to closely 
monitor their consumption of nutrients, anthropometric measurements and blood-test results. The first stage in treating malnutrition is the identification and assessment of the condition. For this reason, doctors and nurses need to complete a comprehensive evaluation of patients from the moment they are admitted to the hospital, working in cooperation with the rest of the professional healthcare team. The European Society of Parenteral and Enteral Nutrition (ESPEN) and other international associations have issued guidelines to follow when using screening tools but these are not enough by themselves. Acting upon the results of screening will play an important role in finding solutions to the problems presented by malnutrition.

\section{References}

1. Soeters PB, Reijven PLM, van Bokhorst-de van der Schueren MAE. Rational approach to nutritional assessment. Clin Nutr 2008;27:706-16.

2. Barker LA, Gout BS, Crowe TC. Hospital Malnutrition: Prevalence, identification and impact on patients and the healthcare system. Int J Environ Res Public Health 2011;8:514-27.

3. Muscaritoli M, Anker SD, Argiles J, et al. Consensus definition of sarcopenia, cachexia and pre-cachexia: Joint document elaborated by Special Interest Groups (SIG)-cachexia-anorexia in chronic wasting diseases and nutrition in geriatrics. ClinNutr 2010;29:154-9.

4. Green SM, Watson R. Nutritional screening and assessment tools for use by nurses: literature review. J AdvNurs 2005;50:69-83.

5. Güngör AE. A study of nutritional status, development of malnutrition and food composition in hospitalized patients. Ankara: Hacettepe University Institute of Health Sciences; 2009.

6. Detsky AS, Mclaughlin JR, Baker JP, et al. What is subjective global assessment of nutritional status? J Parenter Enteral Nutr 1987;11:8-13.

7. Neelemaat F, Kruizenga HM, de Vet HCW, et al. Screening malnutrition in hospital outpatients. Can the SNAQ malnutrition screening tool also be applied to this population? ClinNutr 2008;27:439-46.

8. Kruizenga HM, de Vet HCW, van Marissing CM, et al. The SNAQ (RC), an easy traffic light system as a first step in the recognition of undernutrition in residential care. J Nutr Health Aging 2010;14:83-9.

9. Norman K, Pichard C, Lochs H, et al. Prognostic impact of disease related malnutrition. Clinical Nutrition 2008;27:5-15.

10. Nursal TZ, Noyan T, Atalay BG, et al. Simple two-part tool for screening of malnutrition. Nutrition 2005;21:659-65.

11. Russell CA, Elia M. Nutrition screening survey and audit of adults on admission to hospitals, care homes and mental health units. Nutrition screening survey in the UK in 2007. British Association of Parenteral and Enteral Nutrition 2008;1-39.

12. Korfalı G, Gündoğdu H, Aydıntuğ $S$, et al. Nutritional risk of hospitalized patients in Turkey. Clinical Nutrition 2009;28:533-7.
13. Sungurtekin H, Sungurtekin U, Hanci V, et al. Comparison of two nutrition assessment techniques in hospitalized patients. Nutrition 2004;20:428-32.

14. Bayır H. Investigation of malnutrition rates in open-heart surgery and related risk factors in AbantIzzetBaysal University of Health Research and Application Center. Bolu: Abant Izzet Baysal University Faculty of Medicine, Anesthesiology and Reanimation Department; 2012.

15. Lucchin L, D’Amicis A, Gentile MG, et al. A nationally representative survey of hospital malnutrition: The Italian PIMAI (Project: Iatrojenic Malnutrition in Italy) study. Mediterranean Journal of Nutrition Metabolism 2009;2:171-9.

16. Keith JN. Bedside nutrition assessment past, present, and future: a review of the Subjective Global Assessment. Nutr Clin Pract 2008;23:410-6.

17. Kaba G, Özden A. Enteral tüple beslenme. Güncel Gastroenteroloji 2009;31:3-10.

18. Btaiche IF, Chan LN, Pleva M, et al. Critical illness, gastrointestinal complications, and medication therapy during enteral feeding in critically ill adult patients. NutrClinPract 2010;25:32-49.

19. Elpern E, Stut L, PetersoS, et al. Outcomes associated with enteral tube feedings in a medical intensive care unit. American Journal of Critical Care 2004;13:221-7.

20. Kohli-Seth R, Sinha R, Wilson S, et al. Adult parenteral nutrition utilization at a tertiary care hospital. Nutr Clin Pract 2009;24:728-32.

21. Ziegler TR. Parenteral nutrition in the critically ill patient. N Engl J Med 2009;361:1088-97.

22. Lee H, Koh SO, Park MS. Higher dextrose delivery via TPN related to the development of hyperglycemia in non-diabetic critically ill patients. Nutr Res Pract 2011;5:450-4.

23. Berlana D, Barraquer A, Sabin P, et al. Impact of parenteral nutrition standardization on costs and quality in adult patients(2014);Nutr Hosp 2014;30:351-8.

24. Bodoky G, Kentz-Smith L. Basics in clinical nutrition: Complications of enteral nutrition. e-SPEN, The European e-Journal of Clinical Nutrition and Metabolism 2009;4:209-11.

25. Özbayır T. Effect of the method in intensive care with tube-fed on the frequency and cause of diarrhea. İzmir: Ege Üniversty of Health Sciences Institute; 1995.

26. Karabulut N. Determination of training requirements and knowledge levels of the nurses relating to the care of the patients applied to nasogastric tube. Erzurum: Atatürk University Institute of Health Sciences Surgical Diseases Nursing; 1998.

27. Uysal N, Eşer İ, Korshid L. Hemşirelerin enteral beslenme işlemine yönelik uygulama ve kayıtlarınınin celenmesi. Anadolu Hemşirelik ve Sağlık Bilimleri Dergisi 2011;14:1-9.

28. Dal Ü. Nursing Care of the Patients with Malnutrition. Journal of Hacettepe University School of Nursing 2007;74-81.

29. Horasan E. Hemşirelik Bilim ve Sanatı. İçinde: Aştı T, Karadağ A. Beslenme. İstanbul; Akademi Basın ve Yayıncılık; 2012:898937.

30. Küçük HF, Akyol H, Torlak OA, Eser M, Çolak E, Kaptanoğlu L, Kurt N. Ameliyatlı hastalarda total parenteral beslenme uygulamaları, J Kartal TR 2005;16:1-6. 